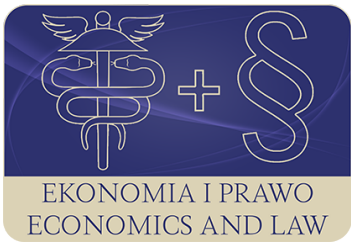

EKONOMIA I PRAWO. ECONOMICS AND LAW

\author{
Volume 20, Issue 3, September 2021 \\ p-ISSN 1898-2255, e-ISSN 2392-1625 \\ www.economicsandlaw.pl
}

ORIGINAL ARTICLE

received 30.03.2021; revised 10.09.2021; accepted 30.09.2021

Citation: Krzyminiewska, G. (2021). Work and its transformations: from statism-based work to the Gig Economy. Ekonomia i Prawo. Economics and Law, 20(3), 573-585. https://doi.org/10.12775/EiP.2021.034.

\title{
Work and its transformations: from statism-based work to the Gig Economy
}

\author{
GRAŻYNA KRZYMINIEWSKA \\ Poznań University of Economics and Business, Faculty of Economics, Department of Sociology \\ and Business Ethics, Al. Niepodległości 10, 61-875 Poznań, Poland \\ ๑razyna.krzyminiewska@ue.poznan.pl \\ (i) orcid.org/0000-0002-1573-3771
}

\begin{abstract}
Motivation: Work as a socio-cultural and -economic phenomenon in the process of Poland's economic transformation within the last thirty years requires special analyses due to its central role both in individual and social terms. To a significant extent, the traditional approach is based on unhelpful separation of economic determinants from the social system as a whole, which is with detriment to the ability to investigate economic process es. Economic phenomena are not the effect of actions of unrelated individuals and their decisions based on rational calculations, but also arise out of the values rooted in their way of thinking and demonstrated through culture.

Aim: This paper is aimed at describing the evolution of work in the context of the changes occurring on the labour market which result from the transformation of these institutions and of the economic culture of Poles. The aim may be achieved by assuming that the experience of the so-called 'cultural turn', a term which perfectly suits to describe the transformation process, requires interest to be taken also in phenomena occurring in everyday life, such as values, attitudes or cultural patterns. The transformation of work and of its meaning for development will be subject to descriptive and comparative analysis in two aspects: (1) with regard to the shift from statism-based economy to flexible forms of employment and the occurrences that accompany that shift and (2) in terms of global economic and technological changes in this regard.

Results: The analyses carried out allowed to describe the changes in the Polish society observed in the area of work. The stages of the changes are identified, and new trends are specified which emerge under the impact of global development and their consequences for the economy and the society.
\end{abstract}


Keywords: work; labour; economic transformation; contemporary trends JEL: Al0; Al30; J400

\section{Introduction}

The social and systemic transformation in the last three decades has been thoroughly investigated, as it has become an unprecedented phenomenon for contemporary Europe (and not only Europe). Countries that took the transformation path decided to adopt the market economy, including its rules and consequences (the opening of markets, liberalisation etc.) and to adopt the principles of democracy. The particular measures, however, varied from country to country, and the 'starting point' was different too, which in various ways affected the economies and societies under transformation. The transformation occurred in many aspects: the economic, social, legal and political one.

For the Polish society, the process involved the coexistence of the elements of both the old and the new order in the collective life, thus Poles dealt both with a continuation and changes in all the aspects of social life. There are plenty of academic works with research on the transformation in Poland, in which the course and the dynamics of changes are analysed. This paper disregards these descriptions on purpose as too extensive and going beyond the research goals adopted for this work. In this paper, focus is placed on the very essence of work and its accompanying institutional aspects, as per the principles of institutional economics and historical sociology, because it is assumed that the problems analysed require an integral and interdisciplinary approach.

The primary aim of this paper is as follows: to describe the evolution of work in the context of the changes occurring on the labour market which result from the transformation of these institutions and of the economic culture of Poles with which we have been dealing in the entire period after 1989. This aim may be achieved by assuming that the experience of the so-called 'cultural turn', a term which perfectly suits to describe the transformation process (see e.g. Alexander, 1988; Geertz, 2005; Jameson, 1998), requires interest to be taken also in the phenomena occurring in everyday life, such as values, attitudes, cultural patterns or the particular elements of the economic culture (Krzyminiewska, 2013).

\section{Literature review}

Work is undoubtedly one of more important notions analysed by various academic disciplines, although their views and definitions of it vary. Regardless of the multiple ways of describing this matter, it is reasonable to believe that the importance of work in human life is exceptional.

The attitude towards work may certainly be an effect of the entire socialisation process experienced by an individual, but it also changes over time along with that individual's circumstances as he or she participates in the labour 
market. The attitudes of an individual (and of the given population as a whole) towards work are a part of a broader process of participating in economic and social life. The mindset with regard to work, i.e. how work is treated, the issues of work ethics (and ethos), is the effect of a number of determinants. The key to these considerations is to capture the variables which form our system of values and beliefs about the world, which finally translate into the attitude towards work. Work and the way it is experienced create the general view of life, of the ascribed and achieved social status, the view of the professional role. Such an approach allows for a broader view of how a population is rooted in culture, creating finally conditions for the adopted behaviours in socio-economic life. This gives grounds to use the assumptions of the essence of economic culture, which is defined by Porter (2003, p. 59) as beliefs, attitudes and values that bear on the economic activities of individuals, organisation and other institutions. Economic culture of a country depends materially on the economic opinions prevailing among that country's citizens. To a large extent, it seems to be the product of the past and the current microeconomic condition.

Descriptions of the particular evolution stages of the essence of work are presented below, and their main characteristics are listed in Table 1.

\subsection{The historical context of work before 1989}

It is reasonable to refer to the historical determinants of the context of work perceived as an economic category, because the experience of socialism and everything with which the Polish society entered the transformation process are determined by generational experience affecting the specific economic culture of Poles and its embedding in the society. Let us note that economic culture is a structure that defines an individual and his or her community by its characteristic properties which determine the existence in economic life. It is possible to understand the shape of economic culture, if the broad economic and social context is analysed from a historical perspective. These determinants are manifold and relate to long historical existence of a community as they created its very foundations. Yet, it is not constant, since new conditions for economic processes and the whole of social life drive its evolution, or at least certain adjustment processes.

Bearing the above in mind, let us note that the character of work in the cultural tradition of the Polish society varied depending on the position of an individual within the society, the individual's position within a particular social class and stratum, but also within the economic system in which he or she had to exist. What is meant here, are various historical turbulences (including life in various systems of the partition economy), which affected the specific nature of what has been assumed with the historical heritage by generations, of what shaped their attitudes to and beliefs about work at most. Researchers agree that the way contemporary people treat work is to a large extent the consequence of the role played in the Polish culture by the values of the gentry and intellectual 
tradition, religious values as well as the organisation of social, political and economic life. And so, in the system of values and beliefs (see: Lewandowski, 1996), a significant role was played by the cult of freedom and independence, bravery and fortitude, with weaker emphasis on the obligation of work, industriousness, diligence, respect for law or mastery in work. Patriotism was measured by readiness to the most heroic sacrifice rather than industriousness. These traditions were to a large extent taken over by the intellectuals of the 19th and 20th centuries (Znaniecki, 1934).

A different mindset about work was presented by non-privileged groups, for which work, due to their position in the society, was the condition of survival. This was typical primarily for the then largest part of the society, peasants. In the traditional system of values of the peasant world, work was not only the way to satisfy needs, but also an important moral norm. The work ethos placed value in the mere process of work rather than its outcome, which could be independent of the effort put by a peasant. Characteristic of the peasant culture was a peculiar type of rationality, which had consequences when aggressive capitalist culture clashed with peasants' traditionalism. Capitalism exists based on formal rationality, which involves extreme economisation of social actions the basis of which is the calculation of profit and expense, whereas characteristic of the peasant culture is the actual rationality type governed by criteria arising out of the acknowledged values, which may not be expressed in quantitative terms of money. Therefore, the chief principle of economic operations is to reduce risk and provide for self-sufficiency rather than to maximise profit (Weber, 1978).

The structure of the economy as affected by the changes resulting from World War 2 and those that changed the economic system after 1945, were a kind of a background through which the rules of the new system permeated.

\subsection{Work and the experience of socialism}

The experience of the Polish society in the socialism period, including with regard to work, was vastly analysed in the literature. There are numerous works of economists, sociologists as well as representatives of other academic disciplines. The scope of this paper will not allow for a critical analysis of these works, it is worthy of note, however, that this exciting read asked questions about the condition of the particular groups within the society, their potential of innovation and adaptation to the conditions of the new reality, questions about the possible trends of change, their scale and intensity.

The rules of command economy did not create favourable conditions for the development of positive attitudes to work; to the contrary: gradually, solutions were introduced which contributed to the collapse of the work ethos. The statism-based economic policy of the state, consisting in the regulation of economic life with administrative measures, contributed to putting down the previously existing entrepreneurship and preventing those who had ran 
private business from acting. It is at that time when the image of the "private initiative' deprecated in the official narrative became rooted among the Polish public opinion. Because of all of that, we may speak of a very specific, even when taking into account the social and economic context in which the then society existed, type of entrepreneurship, which was unclear and only loosely applied the rationality of economic operations within the meaning adopted by liberal doctrines (Nawojczyk, 2009).

The relation between the skills and education of an individual on the one hand and the social acknowledgment and financial situation on the other got increasingly loose. Lacking market competition, full employment, low wages, a lack of relation between the quality of the work performed and the remuneration received for it, all contributed to the decrease of work quality in many areas. There were no systemic incentives fostering individual discipline, initiative and efficient work. The tradition of a 'good job' had clearly collapsed. It seems that socialism consolidated negative phenomena related to work and economic activity inherited from the past generations (see: Krzyminiewska, 1996, p. 169). The way the Polish society treated work was shaped by the entire arrangement of social, political and economic life, and it failed to develop models of work perceived as a means of success. Industriousness or mastery in work were often seen as simply naivety or failure to 'understand the realities', whereas the objectification of a worker in socialism led to the phenomenon which is sometimes referred to by researchers as 'mentality of a hired worker'.

Socialist economy created a labour market based on full employment and statism-based work.

\subsection{Work during the system transformation processes}

As Poland entered the path of the systemic transformation and as a consequence started to introduce the rules of democracy and the free market, Poles (as well as the citizens of other countries under transformation) experienced it as something new and painful. In economic terms, the process put the phenomenon of work in an essentially different position. The model of a worker assumed constant competition, pressure on professional career, self-reliance, and was a novelty for the average Pole. The narrative of the transformation period may be boiled down to the slogan 'Take your faith in your own hands', which caused anxiety among workers, as they had to deal with completely strange and unknown realities.

The transformation turned out to be a shock for the significant majority of workers and enforced redefinition of attitudes to and value of work. First of all, main emphasis was placed on the development of human capital, because the clear enhancement of the status of intellectual work and education resulted from the emerging need for new professions and new skills. Statistical data from various sources (Polish Central Statistical Office, Eurostat) show an 'education boom' triggered by the interest in education with a clear market value. Between 
1995 and 2009, the share of people with higher education in the age group 25-64 raised from $9.7 \%$ to $21.2 \%$. Currently, higher education is the attribute of approximately $4.5 \mathrm{mln}$ of people at this age, which is twice as many as in the mid-1990s, and in 2018 44\% young adults in Poland, according to the report Education at a glance 2019 (OECD, 2019, pp. 1-497), attained a university degree.

Moreover, the labour market created enormous opportunities for entrepreneurial individuals (the image of an entrepreneur and entrepreneurship gradually gained in status), it started to relate the effects of work with the effort put in, but also opened an area of anxiety driven by unemployment or incompatible education and skills as compared to market requirements. At that time, many anomic phenomena on the labour market were observed. Many concerns arose about the ethics of the operations of business, the growth of the grey zone (often forced by business owners from the people they employed). In the following years the labour market stabilised; this stabilisation, though, brought numerous social problems, such as precarisation, reengineering or "junk contracts". The employment structure is presented in Chart 1 .

The labour market in the recent decades has been based on the neoliberal model of a free market, which covered all aspects of social and economic life. The primary goal was defined as the establishment of rules oriented to the maximisation of competitiveness and profits, according to the so-called free market logics, but in fact it leads to the concentration of employers' focus on the reduction of employment costs. The effect of such a way of thinking about the labour market is the spreading idea of increasing this market's flexibility and reducing social security benefits which are seen as a burden for employers.

A direct result of the undertaken measures is a dual labour market, where increasingly wider groups of workers are deprived of social security benefits which are held by people working under standard employment contracts, as well as the increase of profits of stronger economic entities which at the same time do not assume any obligations towards their employees (Musiała, 2018). Precarisation, ${ }^{1}$ i.e., the existence of individuals on the labour market under conditions of uncertain, often (but not always) low-paid work, which is excluded from the social security benefit system, has become a substantial part of the labour market. Definitions of precariat point to a lack of certainty, constancy and stability, chronic inability to predict the future and constant anxiety that it will only bring a worse situation. It is a condition of a fragile and uncertain existence to which a considerable part of the world population is condemned, also in the countries of the capitalist core. It regards people who are temporarily unemployed, earn their living with occasional jobs, are employed under short-term contracts, migrate in search of a job, work part-time or are forced to sign a blank termination notice together with their employment contract. It means a life filled with uncertainty and difficult to plan, a life in which

1 The term 'precariat' is based on the combination of the word precarious and proletariat. The global literature adopted this term owing to Standing (2011; 2014). 
not only the workplace but also the profession itself must be changed several times, where an individual holds the best position one day and loses it the next morning.

Free market rules allowed to introduce new management methods, including reengineering (which means radical changes in business processes to achieve maximum efficiency of an organisation or to reduce costs), reorganisation, flexible working time, reduction of long-term obligations (of all institutions, including the state). On the other hand, the labour market has demonstrated previously unknown reserves of entrepreneurship and readiness to improve one's skills or professional requalification. Work has become not only an instrumental value, as the means and foundation of existence, but also an autotelic value, where self-fulfilment and also social values are of importance (e.g. the activities of social economy entities, activities within social responsibility, sharing economy). The essence of work gains on value.

\subsection{From statism-based work to the Gig Economy}

Work as an economic and social phenomenon constantly evolves under the influence of the society. The recent period has been marked with substantial transformations. These include mainly phenomena arising out of massive changes in the economy resulting from the dynamic developments of technology. This process is called the new economy, innovative economy, economy 4.0 (and with other names), and is based on the labour market of talents, the market of creative individuals who have not problems with combining technological competence with the professional one, with substantial ability of both creating and adopting innovation. The economic structure is driven by innovation in IT and communication technologies and affects all the economy branches, boosting the growth of work efficiency, productivity or the economic growth rate (Borowiecki \& Dziura, 2016, p. 9). Because 'it is an economy based on a growing share of knowledge and information in achieving the economic goal, which is reflected in the development of the knowledge-based technologies and their expansion to all economic operations and processes, which, owing to a feedback with the progressing globalisation, contributes to the modification of the previously valid economic laws' (Żelazny, 2003, pp. 87-104), it means structural and also civilisational changes. Industry 4.0 involves not only technology but also new ways of working and new roles of people in the industry, where the reflection on the competence requirements for the people acting in the labour market, which becomes a labour market of talents, gains on importance. New tendencies on the labour market involve among others the gig economy, which is the result of the changes on the labour market, but also in the workers' culture, which is under transformation driven to a considerable extent by digitalisation. The term 'gig economy' refers to a system of a free market where organisations and independent contractors enter into short-term contracts. Among them are freelancers, consultants, independent contractors and professionals, tempo- 
rary contract workers. These are also individuals working with Uber, Airbnb landlords, online marketplace sellers, volunteers, artists, etc. "Asia has become the center of the 'gig economy'. Pakistan, the Philippines, India, and Bangladesh accounted for the largest amount of operating income. In 2019, they together recorded a 138\% increase in revenue compared to 2018. Therefore, it is in-creasingly heard in professional and scientific circles that by 2030, about half of the world's workforce will be 'gigers'” (Radović-Marković, 2021, pp. 66-67).

If you take a closer look at the statistical data, based on the OLI (Online Labour Index) it can be indicated that there is an increase in the so-called Gig Economy Online (Table 2). On the other hand, in Poland there may be an estimated approx. 320 thousand. gig workers. Most of their services are provided online, 30 percent. it does it on the customer's premises or in both (20\%).

The technological advancement essentially changes how work is organised, how people are hired or how the market space looks like. Table 3 shows a short description of such processes.

\section{Methods}

The specific nature of the matters analysed here requires an interdisciplinary approach to the research. In the contemporary science, 'the demand for an interdisciplinary approach becomes common. Disciplines exchange terms, methods, techniques, sometimes also theoretical models. Areas where two or more disciplines meet become the field of intensive research work, and the culmination of this trend may be observed in the full bloom of hybrid disciplines' (Sztompka, 2004, p. 42). Adopting an interdisciplinary concept of the research allowed for application of the comparative historical approach, which allows to use materials from various periods, which facilitate specifically the explanations concerning the causes of the attitudes of Poles and the phenomenon of the mentality affecting these attitudes. This method, disseminated by Max Weber (he carried out comparative historical studies of the development of the world religions, economies, economics, law etc.), regards a very long historical period, but started to be used by researchers to explain the processes of the socio-economic transformation in the Central and Eastern Europe countries.

The theoretical foundation is based on historical sociology on the one hand, which shows the elements of work related to one another and embedded in the historical context, and on the economic approach according to the new institutional economics on the other, the main idea of which has become to show that institutions important for economic life (especially those of informal nature) are not sufficiently analysed by neoclassical economics. The belief about the mutual impact of economic, cultural and social determinants has become a very important issue (the idea is that the traditional approach is based to a considerable extent on unhelpful isolation of the economic determinants 
from the whole social system (Landreth \& Colander, 1998, p. 563) with detriment to the ability to investigate economic processes.

Finally, the following was applied: the analysis of the dynamics of phenomena, the methods of comparative analysis and cause-and-effect analysis. A study of the relevant literature critical review was carried out and secondary sources were used.

\section{Results}

The analyses carried out allowed for outlining the transformations of the Polish society as it has existed in the area of work. The comparison of the particular periods, from the historical heritage to the latest trends on the labour market, allowed to identify the patterns and values which may be related to work and are present in the mentality and economic culture of Poles. It was analysed which of these changes have become the most susceptible to the impact of social and economic life. The stages of the transformation were identified, as were new trends emerging under the influence of the global development and their consequences for the economy and the society.

\section{Conclusion}

The presented analysis allows for a conclusion that the evolution of the attitudes towards work and its use by all stakeholders of the labour market is driven by the changing legal regulations of how work may be organised as well as macro- and microeconomic determinants. The particular groups within the society develop their own adaptation strategies which bring changes with regard to the values and behaviour patterns in the area of work. A substantial role in this process is played by the globalisation of markets and technology developments, which also drive the emergence of anomic phenomena which adversely affect the situation of workers.

The transformation of work shows that the rule of 'continuity and change' is followed, where attitudes, patterns and values developed in the past are transformed in clash with new economic stimuli. Currently, we are both witnesses and participants of the Covid-19 pandemic, which generates different social and economic circumstances, the effects for work of which are still unclear. There are no doubts, however, that this peculiar situation may bring about major changes in this regard. 


\section{References}

Alexander, J.C. (1988). The new theoretical movement. In N.J. Smelser (Ed.), Handbook of Sociology (pp. 77-102). Sage.

Borowiecki, R., \& Dziura M., (2016). Nowa gospodarka: aspekty wiedzy i innowacji. Przegląd Organizacji, 5, 9-16. https://doi.org/10.33141/ po.2016.05.01.

Geertz, C. (2005). Interpretacja kultur: wybrane eseje. Uniwersytet Jagielloński.

GUS. (2000). Maty rocznik statystyczny. Retrieved 10.09.03.2021 from https:// stat.gov.pl/obszary-tematyczne/roczniki-statystyczne/roczniki-statystyczne/maly-rocznik-statystyczny-2000-r- ,1,1.html? contrast=default.

Jameson, F. (1998). The cultural turn: selected writings on the postmodern 19831998. Verso.

Krzyminiewska, G. (1996). Miejsce pracy w mentalności społeczeństwa polskiego. Ruch Prawniczy, Ekonomiczny i Socjologiczny, 58(3), 165-173.

Krzyminiewska, G. (2013). Kultura ekonomiczna mieszkańców obszarów wiejskich: problemy, przeksztatcenia, wyzwania. Adam Marszałek.

Landreth, H., \& Colander, P.C. (1998). Historia myśli ekonomicznej. PWN.

Lewandowski, E. (1996). Syndromy etniczne spoteczeństw. Uniwersytet Eódzki.

Musiała, A. (Ed.). (2018). Nauka i praktyka w stużbie cztowiekowi pracy: umowy terminowe. Uniwersytet im. Adama Mickiewicza w Poznaniu.

Nawojczyk, M. (2009). Przedsiębiorczość: o trudnościach w aplikacji teorii. Nomos. OECD. (2019). Education at a glance. https://doi.org/10.1787/f8d7880d-en.

Ostoj, I. (2020). Praca w czasach cyfrowych platform technologicznych: w sieci gig economy. Uniwersytet Ekonomiczny w Katowicach.

Porter, M.E. (2003). Postawy, wartości i przekonania a makroekonomia dobrobytu. In L.E. Harrison, \& S.P. Huntington (Eds.), Kultura ma znaczenie (pp. 59-79). Zysk i S-ka.

Radović-Marković, M. (2021). The transformation of work in a global knowledge economy. In M. Radović-Marković, B. Dukanović, D. Marković, \& A. Dragojević (Eds.). Entrepreneurship and work in the gig economy: the case of the western Balkans. Routledge. https://doi.org/10.4324/9781003155409. Standing, G. (2011). The precariat: the new dangerous class. Bloomsbury Academic. Standing, G. (2014). A precariat charter: from denizens to citizens. Bloomsbury Academic.

Sztompka, P. (2004). Współczesna socjologia wśród innych nauk społecznych: burzenie murów i przekraczanie granic. In K. Gorlach, M. Niezgoda \& Z. Seręga (Eds.), Wtadza, naród, tożsamość: studia dedykowane Profesorowi Hieronimowi Kubiakowi (pp. 39-44), Uniwersytet Jagielloński.

Weber, M. (1978). Economy and society. University of California Press.

Żelazny, R. (2003). Nowa gospodarka: mity i rzeczywistość. od fascynacji do naukowego poznania. In T. Bernata (Ed.), Problemy globalizacji gospodarki (pp. 87-104). PTE.

Znaniecki, F. (1934). Ludzie teraźniejsi a cywilizacja przyszłości. Książnica-Atlas. 


\section{Acknowledgements}

Author contributions: author has given an approval to the final version of the article.

Funding: this research was fully funded by the Poznan University of Economics and Business, Institute of Socio-Economics, Department of Sociology and Business Ethics statutory sources.

Note: the results of this study were presented at 9th Scientific Conference: Contemporary Economic Problems 'Thirty years of transformation' (September, 16, 2020, online, Poland). 


\section{Appendix}

\section{Table 1.}

\section{Work in the Polish society in sociological view}

\begin{tabular}{|c|c|c|c|c|}
\hline $\begin{array}{c}\text { Significance of work } \\
\text { before } 1939\end{array}$ & $\begin{array}{c}\text { Socialist ethos } \\
\text { of work }\end{array}$ & $\begin{array}{l}\text { The first decade } \\
\text { of transformation }\end{array}$ & $\begin{array}{l}\text { The second decade } \\
\text { of transformation }\end{array}$ & $\begin{array}{l}\text { The third decade } \\
\text { of transformation }\end{array}$ \\
\hline $\begin{array}{l}\text { - ancient } \\
\text { and Judeo-Chris- } \\
\text { tian/Catholic } \\
\text { duality of attitude } \\
\text { to work } \\
\text { - values } \\
\text { and opinions } \\
\text { based on the cult } \\
\text { of fight with low- } \\
\text { er value of work; } \\
\text { 'tribute of blood' } \\
\text { more important } \\
\text { than 'tribute } \\
\text { of sweat' } \\
\text { - gentry } \\
\text { and intellectual } \\
\text { traditions - } \\
\text { work intended for } \\
\text { people of lower } \\
\text { estates } \\
\text { - work as the con- } \\
\text { dition of existence } \\
\text { for non-privi- } \\
\text { leged classes }\end{array}$ & $\begin{array}{l}\text { - loose relations } \\
\text { between skills } \\
\text { and education } \\
\text { and social recog- } \\
\text { nition and finan- } \\
\text { cial situation } \\
\text { - inconsistency } \\
\text { between work } \\
\text { performed } \\
\text { and remuneration } \\
\text { - mentality } \\
\text { of a hired worker/ } \\
\text { employee } \\
\text { - no developed } \\
\text { incentives } \\
\text { and motivation } \\
\text { to efficient work } \\
\text { and mastery } \\
\text { in work } \\
\text { - no competition } \\
\text { and full employ- } \\
\text { ment }\end{array}$ & $\begin{array}{l}\text { - } \text { shock of transfor- } \\
\text { mation' redefines } \\
\text { the value of work } \\
\text { - } \text { work as an area } \\
\text { of anxiety: unem- } \\
\text { ployment, edu- } \\
\text { cation and skills } \\
\text { incompatible with } \\
\text { market require- } \\
\text { ments } \\
\text { - intellectual work } \\
\text { and proper edu- } \\
\text { cation perceived } \\
\text { as more valuable } \\
\text { than previously } \\
\text { - linking the effects } \\
\text { of work with } \\
\text { the effort put in } \\
\text { - no positive image } \\
\text { of entrepreneur } \\
\text { - anomic conditions } \\
\text { on the labour } \\
\text { market: concerns } \\
\text { about ethical } \\
\text { operations } \\
\text { of business }\end{array}$ & $\begin{array}{l}\text { - interest in edu- } \\
\text { cation which has } \\
\text { a clear market } \\
\text { value } \\
\text { - loosing job } \\
\text { and entering grey } \\
\text { zone } \\
\text { - work as a value } \\
\text { of self-fulfilment } \\
\text { - appreciation } \\
\text { of the image } \\
\text { of entrepreneur } \\
\text { and entrepre- } \\
\text { neurship } \\
\text { - participation } \\
\text { in an open labour } \\
\text { market (including } \\
\text { the eu market) } \\
\text { - orientation } \\
\text { to a professional } \\
\text { career } \\
\text { - anomic conditions } \\
\text { on the labour } \\
\text { market - pre- } \\
\text { carisation, } \\
\text { reengineering, } \\
\text { 'junk contracts' }\end{array}$ & $\begin{array}{l}\text { - expectation } \\
\text { of human capital } \\
\text { with high compe- } \\
\text { tence } \\
\text { - innovation } \\
\text { and competitive- } \\
\text { ness of work } \\
\text { - real skills valued } \\
\text { more than formal } \\
\text { education }\end{array}$ \\
\hline
\end{tabular}

Source: Own preparation.

Table 2.

\section{OLI by country}

\begin{tabular}{lccc}
\hline \multicolumn{1}{c}{ Country } & OLI 2018 & OLI 2019 & OLI 2021 \\
\hline USA & 66.3 & 48.7 & 51.6 \\
Europe & 16.5 & 19.6 & 19.2 \\
other countries of Australia and Oceania & 12.7 & 15.9 & 16.8 \\
Great Britain & 8.8 & 11.2 & 11.4 \\
Canada & 6.3 & 8.4 & 8.5 \\
Australia & 7.7 & 9.1 & 8.1 \\
India & 6.6 & 8.4 & 12.7 \\
Africa & 2.6 & 3.7 & 4.8 \\
other countries of America & 1.8 & 2.6 & 2.7 \\
\hline
\end{tabular}

Source: Own preparation based on Ostoj (2020, p. 41). 
Table 3.

Evolution of the labour market in Poland

\begin{tabular}{|c|c|c|c|}
\hline Area & $\begin{array}{l}\text { Enterprises of the centrally } \\
\text { planned economy }\end{array}$ & $\begin{array}{l}\text { Enterprises of the market economy } \\
\text { in the transformation time }\end{array}$ & Enterprises of the economy 4.0 \\
\hline $\begin{array}{l}\text { labour } \\
\text { market }\end{array}$ & $\begin{array}{l}\text { local, regional, supra-re- } \\
\text { gional market }\end{array}$ & $\begin{array}{l}\text { deregulation of the labour market, } \\
\text { supra-regional nature }\end{array}$ & $\begin{array}{l}\text { global, volatile and unpre- } \\
\text { dictable }\end{array}$ \\
\hline \multirow[t]{2}{*}{ employment } & $\begin{array}{l}\text { employment contract, } \\
\text { generally available work }\end{array}$ & $\begin{array}{l}\text { resignation from standard con- } \\
\text { tracts, instability of employment, } \\
\text { unemployment }\end{array}$ & $\begin{array}{l}\text { untypical employment: flexible } \\
\text { forms, sole proprietors, 'labour } \\
\text { market of talents' }\end{array}$ \\
\hline & & & $\begin{array}{l}\text { labour market mostly absorb- } \\
\text { ing highly skilled employees }\end{array}$ \\
\hline $\begin{array}{l}\text { employer's } \\
\text { position }\end{array}$ & hierarchy-based & employer market & $\begin{array}{l}\text { varies depending on the posi- } \\
\text { tion on the market }\end{array}$ \\
\hline $\begin{array}{l}\text { work } \\
\text { intensity }\end{array}$ & $\begin{array}{l}\text { defined by number of work- } \\
\text { ing hours }\end{array}$ & $\begin{array}{l}\text { outcome orientation, maximisation } \\
\text { of the work intensification }\end{array}$ & mixed system \\
\hline
\end{tabular}

Source: Own preparation.

\section{Chart 1.}

\section{Employed persons}

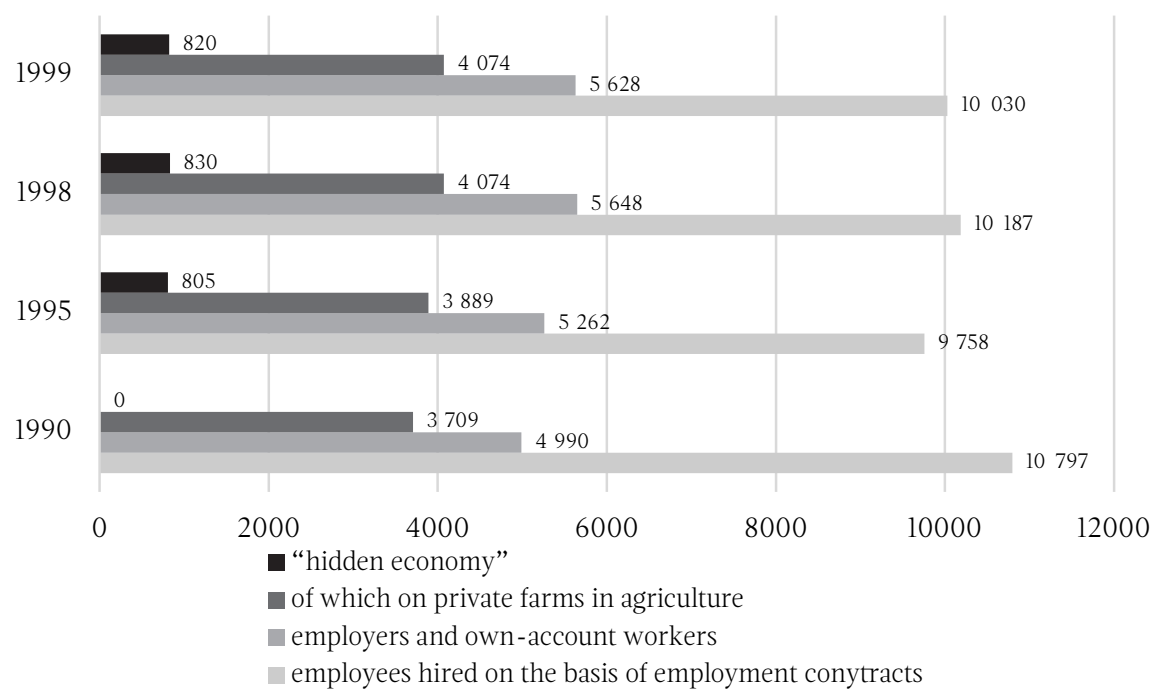

Source: Own preparation based on GUS (2000). 
